\title{
Тромбоз вен портальної системи у хворих на гострий панкреатит
}

\author{
S. M. CHUKLIN, B. YA. PIDHIRNYI
}

Lviv Regional Clinical Hospital

\section{VENOUS THROMBOSIS OF PORTAL SYSTEM IN PATIENTS WITH ACUTE PANCREATITIS}

\begin{abstract}
Одним із місцевих ускладнень гострого панкреатиту є тромбоз вен, зокрема портальної системи. Проте повідомлення в літературі про це є рідкісними. У цьому огляді літератури розглядаються механізми виникнення, патофізіологічні особливості, діагностичні та лікувальні можливості при тромбозі вен портальної системи у хворих на гострий панкреатит.

One of the local complications of acute pancreatitis is venous thrombosis, in particular of portal system. However, reports in the literature about this is rare. In this literature review examined mechanisms of origin, pathophysiologic features, diagnostic and therapeutic possibilities for venous thrombosis of portal system in patients with acute pancreatitis.
\end{abstract}

Перебіг гострого панкреатиту (ГП) у 15-25 \% хворих є тяжким і пов'язаний з потенційно небезпечними для життя місцевими (інфіковані або стерильні некротичні та рідинні скупчення) і системними ускладненнями (органна або поліорганна недостатність, короткочасна або стійка) [1], обидва 3 яких призводять до тривалої госпіталізації, тяжкого перебігу та смертності [2].

Тромбоз вен портальної системи (ТВПС) є одним із місцевих судинних ускладнень ГП. Він може захоплювати ворітну, селезінкову і верхню брижову вени, окремо або в комбінації [3].

Природа ТВПС при ГП не дуже зрозуміла, а літературні відомості обмежені $[4,5,6]$. Частота, клінічне значення і довгострокові наслідки не дуже добре описані порівняно з хронічним панкреатитом [7].

ТВПС у більшості випадків не викликає якихнебудь додаткових симптомів i, звичайно, виявляється випадково при радіологічних обстеженнях, які виконуються для оцінки тяжкості панкреатиту [8]. Проте він може призвести до таких серйозних клінічних наслідків, як печінкова недостатність через оклюзію ворітної вени, набряк та ішемія тонкої і товстої кишок через оклюзію верхньої брижової вени, гіперспленізм, спонтанний розрив селезінки, субкапсульна гематома селезінки, а пізніше до шлунково-кишкової кровотечі з варикозно розширених вен (особливо при так званій сегментарній або лівобічній портальній гіпертензії) [3]. Ці наслідки можуть мати значний несприятливий вплив на перебіг захворювання і кінцевий прогноз [4, 9, 10].
Частота ТВПС у всіх пацієнтів із ГП є відносно низькою, а ускладнення, безпосередньо пов'язані 3 ТВПС, рідкісні [7, 11].

Частота ТВПС у різних дослідженнях коливається від 1 до 24 \%, залежно від тяжкості (легкий порівняно з тяжким панкреатитом, гострий порівняно із хронічним панкреатитом) досліджуваної популяції і методів візуалізації (УСГ порівняно 3 KT) $[8,12,13]$. У ретроспективному дослідженні [7] виявили 45 пацієнтів із ТВПС серед 2454 пацієнтів із гострим панкреатитом (частота 1,8 \%) протягом 10 років порівняно з рівнем у 22,6 \% в метааналізі Butler J. R. зі співавт. [4]. Цей метааналіз міг переоцінити справжню частоту ТВПС через включення 52 повідомлень про випадки тромбозу селезінкової вени, тому що багато досліджень у минулому повідомили про домінування цього виду при тяжкому панкреатиті. Ізольоване ураження селезінкової вени (38 \%) було поширенішим, ніж поодиноке залучення ворітної вени (16 \%). Селезінкова вена або окремо, або в комбінації була залучена в процес у 30 (67 \%) з 45 пацієнтів. У більшості пацієнтів з венозним тромбозом був некротичний панкреатит (58 \%), але навіть при легкому ГП спостерігався ТВПС, ймовірно, через перипанкреатичне запалення.

У нещодавньому дослідженні [14] ТВПС був діагностований у 42 зі 115 хворих на ГП (36,5 \%), що було вище за попередні результати. Вища частота, мабуть, спостерігалася за рахунок виключення пацієнтів без некрозу. 
ТВПС частіше пов'язаний із гострим некротичним панкреатитом, зокрема з наявністю, розташуванням і розповсюдженістю панкреонекрозу [11]. Ретроспективне дослідження нещодавно показало, що у 53 \% пацієнтів із некрозом розвивається ТВПС [11]. Інша робота це підтвердила [15], вказуючи, що приблизно у 4 з 10 пацієнтів із гострим некротичним панкреатитом спостерігається ТВПС.

Інфаркт печінки при гострому панкреатиті буває дуже рідко через унікальну судинну конфігурацію печінки [16]. Печінка має подвійне артерійне і венозне кровопостачання і венозний відтік [17]; крім того, багата мережа внутрішньо- і позапечінкових допоміжних і колатеральних артерій у цьому органі створює складну компенсаторну систему в разі зниження або відсутності кровотоку [18]. Описаний тромбоз ворітної і печінкової вени з інфарктом печінки у хворого на гострий панкреатит [19].

Що стосується часу виникнення ТВПС при ГП [7], то він був відзначений на початку тільки у 8 (18 \%) з 45 пацієнтів. У дев'ятнадцяти хворих (42 \%) тромбоз був діагностований протягом одного місяця, і ще у 18 (40 \%) - від 1 місяця до 1 року від початку ГП. Проте виявлення у 36 \% 3 них колатералей на КТ, в $11 \%$ - варикозно розширених вен при ендоскопії дозволяє припустити, що у цих пацієнтів поява ТВПС була безсимптомною, і тромбоз виявлявся пізніше, у присутності колатералей або варикозного розширення вен.

До сьогодні детальний патогенез виникнення ТВПС при ГП залишається нез'ясованим і може включати в себе безліч клінічних факторів.

Різке підвищення прокоагулянтних медіаторів запалення, застій, спазм судин, ефекти від навколишньої запаленої підшлункової залози спричинюють тромбоз при гострому панкреатиті [20], тоді як при хронічному панкреатиті (ХП) він виникає внаслідок пошкодження інтими при повторному гострому запаленні, хронічному запаленні із фіброзом, стисненні псевдокістою або збільшеною запаленою підшлунковою залозою [21].

У патогенез ТВПС при ГП можуть бути залучені різноманітні фактори, такі як набряк, клітинна інфільтрація і запальний процес, які можуть залучати вену безпосередньо і викликати пошкодження інтими, або панкреатичні i/або перипанкреатичні рідинні скупчення, або збільшена паренхіма підшлункової залози можуть стиснути вену, що призведе до застою і ТВПС. В опублікованому дослідженні [7] 24 (53 \%) з 45 пацієнтів мали скупчення рідини, без усякого зв'язку між розміром скупчення та ТВПС. Підвищення запальних медіаторів, таких як фактор некрозу пухлин- $\alpha$, інтерлейкін-1 $\beta$ та інтерлейкін-6, не тільки опосередковує систем- не запалення, але також може призвести до системної активації гемостазу в цих пацієнтів, у результаті чого виникає агрегація тромбоцитів і тромбіну, багатого фібрином. Крім того, активація коагуляції, опосередкована запаленням, пряме проникнення панкреатичного тканинного фактора в кров можуть ініціювати коагуляцію.

Відомо, що ТВПС частіше виникає у пацієнтів із тяжким панкреатитом [5], але $\epsilon$ мало даних про фактори ризику даного ускладнення. Периваскулярне запалення і компресія перипанкреатичними скупченнями або панкреонекрозом збільшують частоту ТВПС $[5,8]$.

У нещодавньому дослідженні [14] були проаналізовані дані пацієнтів із гострим некротичним панкреатитом (ГНП) з метою дослідження факторів ризику розвитку ТВПС. Крім того, також вивчали прогноз у хворих на ГНП з або без ТВПС, оцінили 15 потенційних факторів ризику ТВПС у хворих на ГНП. Було виявлено, що внутрішньочеревний тиск $\epsilon$ незалежним прогностичним фактором. КТ критерії Balthazar Е. і виникнення інфікованого панкреонекрозу також корелювало з ТВПС, але менш сильно. Отримані результати [14] свідчать про те, що хворі на ГНП у поєднанні з ТВПС триваліше перебували в стаціонарі, мали більше ускладнень, вищу смертність і потребували інвазійніших процедур.

Постійне підвищення внутрішньочеревного тиску або внутрішньочеревна гіпертензія з розвитком абдомінального компартмент-синдрому є частими у хворих на ГП [22]. Коли внутрішньочеревний тиск сягає 10-15 мм рт. ст., мікроциркуляція в слизовій оболонці шлунка, кірковому шарі нирки i, особливо, у серозному і м'язовому шарі стінки тонкої і товстої кишок буде значно порушена або навіть відсутня, що полегшує формування тромбозу [23]. У представленому дослідженні [14] середній внутрішньочеревний тиск у пацієнтів із ТВПС був 11,25 мм рт. ст. (квартиль: 8,75-17,75 мм рт. ст.), що дуже близько до діагностичних критеріїв внутрішньочеревної гіпертензії. Таким чином, внаслідок порушення капілярного кровотоку зменшується потік крові у спланхнічних венах, що може сприяти тромбоутворенню в деяких пацієнтів.

Кілька досліджень показали, що некроз підшлункової залози і вторинна інфекція беруть участь у патогенезі ТВПС [5], що відповідає іншим результатам [14], оскільки у пацієнтів з інфікованим панкреонекрозом і високим показником Balthazar Е. спостерігали високий ризик ТВПС. Панкреонекроз, як вважають, пов'язаний із тяжкою місцевою запальною реакцією і може оточувати вену безпосередньо, у результаті чого порушується вазомоторна функція, 
знижується перфузія капілярів і підвищується тромбоз, особливо, коли виникає вторинна інфекція. Крім того, паранефральний некроз (дуже поширений у хворих на ГП) може безпосередньо негативно впливати на селезінкову вену, у результаті чого виникає іï тромбоз. Таким чином, через анатомічні характеристики системи ворітної вени і характер некрозу підшлункової залози своєчасне дренування [24] може значно зменшити місцеве запалення, що знизить ризик ТВПС.

Деякі дослідження показали системний гіперкоагуляційний або протромботичний стан при ГП і його потенційний взаємозв'язок $з$ клінічними результатами i ТВПС [25, 26]. D-димер, який в основному використовується як ефективний діагностичний критерій тромбозу глибоких вен, а також легеневої емболії [27], має значний передбачувальний рівень у ранній фазі ГП [28]. Проте інше дослідження [14] не показало жодної кореляції між D-димером і розвитком ТВПС, припускаючи, що коагуляційні порушення при ГП не можуть бути безпосередньою причиною ТВПС. ТВПС може бути результатом прямого запального процесу і не обов'язково пов'язаний з протромботичним або гіперкоагуляційним станом [29].

Дослідження, яке було проведене Rebours V. зі співавт. [29], оцінило тромбофілічні фактори ризику в пацієнтів з алкогольним гострим/хронічним панкреатитом. Вони дійшли висновку, що ТВПС виникає частіше через локальне запалення, ніж через будь-який тромбофілічний стан.

Оскільки хвіст підшлункової залози анатомічно розташований біля воріт селезінки, запалення навколо хвоста підшлункової залози є передумовою для розвитку тромбозу селезінкової вени [30]. Селезінкові ускладнення, пов'язані $з$ тромбозом селезінкової вени, проявляються у вигляді спонтанного розриву селезінки (СРС) або субкапсульної гематоми [30].

Венозний тромбоз при панкреатиті може бути також класифікований на підставі механізму розвитку тромбозу: непрямий, при якому збільшуються прокоагулянтні медіатори запалення, або прямий, коли кіста підшлункової залози впадає безпосередньо у вену (фістулізація вена-псевдокіста). Останнє було описано, як правило, для ворітної вени. Нориця між ворітною веною і псевдокістою може проявлятися клінічно нез'ясованим болем у животі [31] або вельми поширеним жировим некрозом [31, 32]. Hammar A. М. зі співавт. описали пацієнта 3 рецидивним артритом, підшкірним, суглобовим i кістковим некрозом з норицею між ворітною веною і псевдокістою підшлункової залози [33].

Нориця між псевдокістою і ворітною веною зазвичай спостерігається у чоловіків, особливо при алкогольному панкреатиті [31]. Механізм фістулізації включає ерозування венозної стінки активними ферментами із сусідньої псевдокісти з початковим формуванням тромбу. Пізніше відбувається лізис тромбу і заповнення вени соком підшлункової залози [34]. Оскільки псевдокіста є зоною високого тиску, значна кровотеча виникає рідко [31].

Симптоматика ТВПС залежить від швидкості розвитку тромбозу і компенсації кровотоку внутрішніх органів. У більшості хворих початок тромбозу є безсимптомним, але, як правило, спостерігаються симптоми панкреатиту. Часто складним завданням $€$ відрізнити біль через тромбоз від болю від панкреатиту. ТВПС може призвести до кровотечі, ішемії кишок і печінкової недостатності [5,35], але ознаки і симптоми можутьперекриватися симптомами гострого панкреатиту. Крім того, колатералі й варикозне розширення вен, викликані ТВПС, збільшують ризик кровотечі під час малоінвазійних процедур [6].

Тромбоз брижової венозної системи також може бути передвісником гострого ускладнення. Тромботична оклюзія вен може призвести до інфаркту кишок [36, 37]. Ступінь і тяжкість інфаркту поряд з іншими супутніми захворюваннями передбачає кінцевий результат. Ішемічна атака, якщо є легкою, може імітувати пухлинний процес [38]. 3 іншого боку, гангрена [37] або перфорація [37, 39, 40] кишки настає, якщо ішемічне пошкодження $є$ серйозним. Слизова оболонка кишок може виразкувати, і це може бути пов'язано з панікулітом брижі [36]. Інфаркт кишок при панкреатиті є вторинним відносно венозного тромбозу і був описаний для порожньої [36, 40, 41] і товстої кишок [37, 39]. Nottle P. зі співавт. [39] повідомили про випадок гострого панкреатиту з інфарктом товстої кишки 3 перфорацією, яка була лікована субтотальною колектомією та ілеостомією, з відстроченим ілеосигмоїдним анастомозом. В іншому дослідженні [7] тільки 2 пацієнти мали ознаки ішемії тонкої кишки і некроз, які потребували резекції.

Клінічні симптоми спонтанного розриву селезінки включають біль у лівому підребер'ї, артеріальну гіпотензію [42, 43]. Симптом Kehr може бути позитивним [42].

Що стосується клінічних результатів, то наведені дані [14] показують, що пацієнти з ТВПС були набагато тяжчі, а прогноз - надзвичайно несприятливим, що підтверджується тривалішим перебуванням у відділенні інтенсивної терапії і в лікарні в цілому та помітно вищою летальністю (23,8 \% порівняно з 9,6 \%; p=0,03). Ця розбіжність може бути пов'язана, головним чином, з таким: по-перше, частота тяжкого набряку кишок або ішемії, викликаної 
обструкцією венозного рефлюксу і венозним застоєМ, збільшується, коли супроводжується ТВПС. У хворих на ГНП, ускладнений ТВПС, як правило, $\epsilon$ непереносимість до раннього ентерального харчування, яке, як вважають, має велике клінічне значення в лікуванні ГП [44]. По-друге, асцит, викликаний тромбозом верхньої брижової вени, може також сприяти подовженому перебуванню хворого в стаціонарі, особливо коли хільозний асцит виникає через розрив брижових лімфатичних судин [45]. Додаткове використання парентерального харчування може також збільшити ризик деяких серйозних ускладнень. По-третє, збільшення селезінки часто супроводжує ТВПС, а ії̈ ускладнення, такі як тромбоцитопенія або панцитопенія, можуть призвести до порушень згортання крові. Спленомегалія часто спостерігається у хворих із ТВПС. Частота спленомегалії складає від 52 до 71 \%. Іноді це супроводжується болем у ділянці селезінки, лейкопенією і тромбоцитопенією [4]. Нарешті, варикозне розширення вен шлунка, спричинене ТВПС, пов'язане з вищою частотою спонтанної кровотечі, яка призводить до анемії і гематогенного інфікування.

ТВПС, звичайно, не проявляється вираженим асцитом, якщо у пацієнтів не розвивається гостра дилатаційна гіпоальбумінемія внаслідок інфузійної терапії при варикозній кровотечі.

Кровотеча з варикозно розширених вен шлунка внаслідок лівобічної портальної гіпертензії при тяжкому гострому панкреатиті $є$ досить рідкою, особливо в гострій стадії. Повідомлення про це лише епізодичні, а остаточний метод лікування таких ускладнень $є$ іноді складним і суперечливим [46, 47]. Вказувалося, що тільки у 5 (11 \%) хворих на ГП розвинулися ендоскопічно видимі варикозні вузли, тоді як 16 (36 \%) мали колатералі [7], видимі на КT. Проте тільки в одного пацієнта розвинулася кровотеча з варикозних вузлів, яка потребувала лігування варикозно розширених вен. Таким чином, кровотеча $з$ варикозних вузлів у зв'язку 3 ТВПС трапляється рідко (2,2 \%). До аналогічного висновку прийшли Butler J. R. зі співавт. [4], в яких частота варикозу склала 53 \% (гострий і хронічний панкреатит) із кровотечею у 6 \% хворих на ГП. Реканалізація була відзначена у 5 з 45 пацієнтів [7]. Був описаний випадок масивної кровотечі з вариксів шлунка, спричинених лівобічною портальною гіпертензією при тяжкому гострому панкреатиті [48], яка розвинулась на 7-му добу розвитку ГП. Для зупинки кровотечі була застосована ендоскопічна клейова адгезія, проте через 12 год відбулася повторна кровотеча, яка була зупинена емболізацією селезінкової артерії і коротких вен шлунка.
Діагностика ТВПС при ГП грунтується на клінічних і радіологічних даних.

Звичайна ангіографія більше не використовується як тест першої ланки для діагностики ТВПС. Проте вона $є$ доцільною в окремих пацієнтів, коли передбачається локальне транскатетерне введення тромболітиків або вазодилататорів. На сьогодні діагностична ангіографія зазвичай зарезервована для випадків, у яких клінічно підозрюється портомезентеріальний венозний тромбоз, але не встановлений неінвазійними методами.

Доплерографія 3 дуплексним скануванням $є$ неінвазійним і відносно недорогим методом. Alpern M. D. зі співавт. [49] встановили чутливість методу в 83 \% для візуалізації тромбозу ворітної вени. Проте, незважаючи на чудові результати для візуалізації ворітної вени, метод може бути менш точним воцінці селезінковоївеничерезіїанатомічне розташування. Недоліки методу: проблеми зі знаходженням відповідного акустичного вікна, перекриття вен портальної системи газом у кишках, утруднена візуалізація глибоко розташованих варикозно розширених вен, помилкове сприйняття великих колатеральних судин за основні вени [50]. Для точнішої візуалізації судин портальної системи може бути використана ендоскопічна ультрасонографія [51].

Комп'ютерна венографія стала звичайною процедурою для оцінки судинної системи черевної порожнини, зокрема колатеральних судин [52]. Однак, лише деякі дослідження оцінили ефективність цього методу для виявлення ТВПС у хворих на гострий некротичний панкреатит. У своєму дослідженні [15] автори прагнули оцінити діагностичну точність комп'ютерної венографії для виявлення ТВПС при ГНП порівняно $з$ цифровою субтракційною ангіографією (ЦСА).

Було визначено [15], що ТВПС має високу частоту в пацієнтів із гострим некротичним панкреатитом, і комп'ютерна венографія має високі позитивні й негативні прогностичні значення для візуалізації ТВПС. Ці дані дозволяють зазначити, що комп’ютерна венографія може служити альтернативою методу для скринінгу та оцінки ТВПС при цій патології.

ЦСА $€$ інвазивною і трудомісткою процедурою, яка, як правило, виконується тільки тоді, коли тромбоз виявляється клінічно або вірогідно підозрюється. На відміну від цього, комп’ютерна ангіографія $€$ неінвазійною і швидкою процедурою, яка може бути легко виконана після контрастно-підсиленої KT [53, 54]. Крім того, комп’ютерна ангіографія також показує позасудинні аномалії, набряк брижі і взаємовідношення між перипанкреатичним не- 
крозом і судинами [8]. Таким чином, комп'ютерна томографія придатніша для скринінгу пацієнтів із ГНП. На додаток до технічних питань, результати комп’ютерної томографії більше залежать від екстраваскулярних аномалій. У цій роботі [15] два діагнози при комп’ютерній томографії відрізнялися від діагнозів при ЦСА. Таким чином, при КТ було два хибнопозитивні результати. В одному випадку були встановлені множинні дефекти наповнення, в іншому не було чіткого зображення.

Одним з обмежень дослідження [15] є те, що в проміжку між КТ венографією і ЦСА стан вісцеральної системи може змінитися. Крім того, розмір вибірки не був достатньо великим, і це було одноцентровим ретроспективним дослідженням.

МРТ є одним з провідних досліджень для візуалізації підшлункової залози і навколишніх судин внаслідок відсутності радіаційного навантаження. Перевагою $\epsilon$ те, що стан портальної системи може бути оцінений навіть без контрастування [55]. Сучасна тривимірна контрастна МР-ангіографія дає можливість добре візуалізувати частковий тромбоз [56].

Важливо також точно оцінити ступінь пошкодження печінки при їі інфаркті. Звичайна комп’ютерна томографія (КТ), як правило, вважається найкориснішим методом діагностики цього стану [57]. Втім, інфаркт печінки найкраще оцінювати 3 двох точок зору: печінкової гемодинаміки і гепатоцелюлярної функції. Для цього краще використовувати контрастно-підсилену мультидетекторну КТ і динамічну МРТ.

Для запобігання ТВПС відповідну декомпресію у хворих із постійно підвищеним внутрішньочеревним тиском слід розглядати відразу після встановлення діагнозу внутрішньочеревної гіпертензії. Світове товариство з абдомінального компартмент-синдрому [58] запропонувало використовувати черезшкірне катетерне дренування для видалення рідини (в умовах явної внутрішньочеревної рідини) у пацієнтів з абдомінальним компартментсиндромом, коли це технічно можливо (ступінь 2 C). Крім того, враховуючи ризик вторинної панкреатичної інфекції, слід уникати екстреної лапаротомії, якщо внутрішньочеревна гіпертензія не викликає особливої стурбованості. Оскільки рідинні скупчення $\epsilon$ частими в ранній фазі ГП, черезшкірне дренування може бути оптимальним вибором для декомпресії i, можливо, знизить, деякою мірою, частоту ТВПС.

Спонтанний розрив селезінки зазвичай вимагає хірургічного втручання. Лікування грунтується на гемодинамічній стабільності, ступені гемоперитонеуму і тяжкості пошкодження селезінки [43]. Активного втручання не потрібно, якщо па- цієнт гемодинамічно стабільний; ці пацієнти можуть перебувати під пильним клінічним і сонографічним контролем. Консервативний підхід був обгрунтований Mujtaba G. зі співавт. у гемодинамічно стабільного пацієнта 3 гострим панкреатитом (із хворобою Crohn), в якого виник спонтанний розрив селезінки внаслідок тромбозу селезінкової вени [43]. Аналогічно Rypens F. зі співавт. [59] запропонували вичікувальну тактику, оскільки ускладнення з боку селезінки при панкреатиті можуть з часом регресувати. Навпаки, хірургічне втручання $є$ виправданим, якщо у пацієнта спостерігається різке падіння артеріального тиску або з'являються ознаки перитоніту [43].

На сьогодні не існує загальноприйнятих рекомендацій щодо застосування антикоагулянтів при ТВПС. Літературні дані вказують на повну і часткову реканалізацію ворітної вени у 38,3 і 14,0 \% після застосування антикоагулянтів при гострому тромбозі ворітної вени [60,61]. Але внаслідок високої частоти спонтанної реканалізації ізольований тромбоз селезінкової вени не $є$ показанням для антикоагуляційної терапії. У дослідженні Gonzelez H. J. зі співавт. [5] серед 10 пацієнтів із тромбозом ворітної вени 4 отримували антикоагулянти і 6 - не отримували. Не було ніякої різниці в темпах реканалізації у 2 групах.

Хоча найчастіше тромбованою веною при ГП є селезінкова внаслідок вторинної компресії, тромбоз ворітної вени $€$ найпоширенішим показанням для призначення пероральних антикоагулянтів [7]. Сімнадцять пацієнтів лікувалися гепарином з подальшим призначенням короткодіючих пероральних антикоагулянтів з варфарином. В 11 із 17 хворих був тромбоз ворітної вени. Чотири пацієнти мали на додаток тромбоз глибоких вен i/або легеневу емболію. Тільки у двох хворих при застосуванні антикоагулянтів відзначено реканалізацію порівняно з 3 пацієнтами без їх призначення (p>0,05, не має істотного значення). Кровотечі були відзначені у 2 хворих при прийманні антикоагулянтів проти 5 пацієнтів без застосування $(\mathrm{p}>0,05)$. Цей факт дозволяє припустити, що антикоагулянти не підвищують ризик кровотеч у хворих на ГП, коли застосовуються за відповідними показаннями. Грунтуючись на цих висновках, автори вважають [7], що антикоагулянтна терапія доцільна у всіх хворих із ТВПС. Тривалість лікування повинна бути від 3 до 6 місяців, залежно від реканалізації. Майбутні перспективні дослідження, однак, необхідні, щоб підтвердити або спростувати результати цього дослідження.

Ендоваскулярна катетерспрямована тромболітична терапія може бути застосована для лікування гострого симптоматичного ТВПС. Втім, такий ме- 
тод не використовували при гострому панкреатиті.

У лікуванні варикозного розширення вен у хворих на ГП доцільно користуватися консенсусом Baveno V [62]:

1. Первинна профілактика: у пацієнтів з варикозно розширеними венами шлунка можливе застосування $\beta$-блокаторів (надолол або пропранолол).

2. Лікування варикозної кровотечі:

а) ендоскопічна терапія при варикозно розширених венах стравоходу;

б) лігування при гострій стравохідній варикозній кровотечі; склеротерапія може бути використана, якщо лігування технічно є складним;

\section{СПИСОК ЛІТЕРАТУРИ}

1. Early systemic inflammatory response syndrome is associated with severe acute pancreatitis / V. K. Singh, B. U. Wu, T. L. Bollen [et al.] // Clin. Gastroenterol. Hepatol. - 2009. - Vol.7. - P. 1247-1251.

2. Organ failure and infection of pancreatic necrosis as determinants of mortality in patients with acute pancreatitis / M. S. Petrov, S. Shanbhag, M. Chakraborty [et al.] // Gastroenterology. - 2010. - Vol.139. - P. 813-820.

3. Mallick I. H. Vascular complications of pancreatitis/ I. H. Mallick, M. C. Winslet // JOP. - 2004. - Vol.5. - P. 328-337.

4. Natural history of pancreatitis-induced splenic vein thrombosis: a systematic review and meta-analysis of its incidence and rate of gastrointestinal bleeding / J. R. Butler, G. J. Eckert, N. J. Zyromski [et al.] // HPB (Oxford). - 2011. - Vol.13. - P. 839-845.

5. Splanchnic vein thrombosis in severe acute pancreatitis: a 2-year, single-institution experience / H. J. Gonzelez, S. J. Sahay, B. Samadi [et al.] // HPB (Oxford). - 2011. - Vol.13. - P. 860864.

6. Besselink M. G. Splanchnic vein thrombosis complicatig severe acute pancreatitis / M. G. Besselink // HPB (Oxford). 2011. - Vol.13. - P. 831-832.

7. Splanchnic vein thrombosis in acute pancreatitis: a singlecenter experience / S. Harris, N. A. Nadkarni, H. V. Naina, S. S. Vege // Pancreas. - 2013. - Vol. 42. - P. 1251-1254.

8. Nadkarni N. A. Splanchnic venous thrombosis and pancreatitis / N. A. Nadkarni, S. Khanna, S. S. Vege // Pancreas. - 2013. Vol.42. - P. 924-931.

9. Report of 24 left-sided portal hypertension cases: a singlecenter prospective cohort study / S. Koklu, O. Yuksel, M. Arhan [et al.] // Dig. Dis. Sci. - 2005. - Vol.50. - P. 976-982.

10. Park D. E. Chylous ascites caused by acute pancreatitis with portal vein thrombosis / D. E. Park, K. M. Chae // J. Korean Surg. Soc. - 2011. - Vol.81, Suppl.1. - P. 64-68.

11. Portosplenomesenteric venous thrombosis in patients with acute pancreatitis is associated with pancreatic necrosis and usually has a benign course / J. Easler, V. Muddana, A. Furlan [et al.] // Clin. Gastroenterol. Hepatol. - 2014. - Vol.12. - P. 854862.

12. Peripancreatic vascular abnormalities complicating acute pancreatitis: contrast-enhanced helical CT findings / K. J. Mortele, P. J. Mergo, H. M. Taylor [et al.] // Eur. J. Radiol. - 2004. Vol. 52. - P. 67-72.

13. Vascular complications in acute pancreatitis assessed by color duplex ultrasonography / T. Dorffel, T. Wruck, R. I. Ruckert [et al.] // Pancreas. - 2000. - Vol. 21. - P. 126-133. в) ендоскопічна терапія 3 клеєм (наприклад, N-butylcyanoacrylate) при гострій кровотечі 3 ізольованих вен шлунка і шлунково-стравохідних вариксів 2 типу (GOV2), які виходять за кардію;

г) лігування або використання клею при кровотечі зі шлунково-стравохідних вариксів 1 типу.

3. Вторинна профілактика: ефективна ендоскопічна терапія. Існують докази, що $\beta$-блокатори також ефективні.

Отже, враховуючи сучасні відомості про ТВПС при гострому панкреатиті, необхідні подальші проспективні дослідження для розпрацювання протоколу скринінгу і лікування цієї патології.

14. Risk factors and outcome of splanchnic venous thrombosis in patients with necrotizing acute pancreatitis / J. Zhou, L. Ke, Z. Tong [et al.] // Thrombosis Research. - 2015. - Vol.135. P. 68-72.

15. Splanchnic vein thrombosis in necrotizing acute pancreatitis: Detection by computed tomographic venography / W. Jiang, J. Zhou, L. Ke [et al.] // World J. Gastroenterol. - 2014. - Vol. 20. - P. 16698-16701.

16. Hepatic infarcts: new observations by CT and sonography / A. S. Lev-Toaff, A. C. Friedman, L. M. Cohen [et al.] // Am. J. Roentgenol. - 1987. - Vol. 149. - P. 87-90.

17. Demachi H. Scanning electron microscopy of intrahepatic microvasculature casts following experimental hepatic artery embolization / H. Demachi, O. Matsui, T. Takashima // Cardiovasc. Intervent. Radiol. - 1991. - Vol.14. - P. 158-162.

18. Itai Y. Blood flow and liver imaging / Y. Itai, O. Matsui // Radiology. - 1997. - Vol. 202. - P. 306-314.

19. Hepatic Infarction complicated with acute pancreatitis precisely diagnosed with gadoxetate disodium-enhanced magnetic resonance imaging / M. Maruyama, A. Yamada, Y. Kuraishi [et al.] // Intern. Med. - 2014. - Vol. 53. - P. 2215-2221.

20. Should anticoagulants be administered for portal vein thrombosis associated with acute pancreatitis? / W. S. Park, H. I. Kim, B. J. Jeon [et al.] // World J. Gastroenterol. - 2012. Vol.18. - P. 6168-6171.

21. Sakorafas G. H. Splenic-vein thrombosis complicating chronic pancreatitis / G. H. Sakorafas, A. G. Tsiotou // Scand. J. Gastroenterol. - 1999. - Vol. 34. - P. 1171-1177.

22. Results from the International conference of experts on intraabdominal hypertension and abdominal compartment syndrome. I. Definitions / M. L. Malbrain, M. L. Cheatham, A. Kirkpatrick [et al.] // Intensive Care Med. - 2006. - Vol.32. - P. 1722-1732. 23. Gastrointestinal microcirculation and cardiopulmonary function during experimentally increased intra-abdominal pressure // P. H. Olofsson, S. Berg, H. C. Ahn [et al.] // Crit. Care Med. - 2009. - Vol. 37. - P. 230-239.

24. Percutaneous catheter drainage for infective pancreatic necrosis: is it always the first choice for all patients? / Z. Tong, W. Li, W. Yu [et al.] // Pancreas. - 2012. - Vol.41. - P. 302305.

25. The relationship of coagulation factors to clinical complications of acute pancreatitis / J. H. Ranson, H. Lackner, I. R. Berman, R. Schinella // Surgery. - 1977. - Vol.81. - P. 502-511.

26. Lasson A. Disseminated intravascular coagulation and antiprotease activity in acute human pancreatitis / A. Lasson, 
K. Ohlsson // Scand. J. Gastroenterol. - 1986. - Vol.126, Suppl. - P. 35-39.

27. Evaluation of D-dimer in the diagnosis of suspected deepvein thrombosis / P. S. Wells, D. R. Anderson, M. Rodger [et al.] // N. Engl. J. Med. - 2003. - Vol. 349. - P. 1227-1235.

28. Coagulative disorders in human acute pancreatitis: role for the D-dimer / T. Salomone, P. Tosi, G. Palareti [et al.] // Pancreas. 2003. - Vol.26. - P. 111-116.

29. Extrahepatic portal venous system thrombosis in recurrent acute and chronic alcoholic pancreatitis is caused by local inflammation and not thrombophilia / V. Rebours, L. Boudaoud, M. P. Vullierme [et al.] // Am. J. Gastroenterol. - 2012. - Vol.107. - P. 1579-1585.

30. Patil P. V. Splenic parenchymal complications in pancreatitis / P. V. Patil, A. Khalil, M. A. Thaha // JOP. - 2011. - Vol.12. - P. 287-291.

31. Spontaneous pancreatic pseudocyst-portal vein fistula: a rare and potentially life-threatening complication of pancreatitis / S. S. Raza, A. Hakeem, M. Sheridan, N. Ahmad // Ann. R. Coll. Surg. Engl. - 2013. - Vol. 95. - P. 7-9.

32. Pancreatic-portal fistula and subcutaneous fat necrosis / R. Delcenserie, A. Bental, A. Goll [et al.] // Gastroenterol. Clin. Biol. - 1994. - Vol. 18. - P. 1132-1137.

33. Pancreatic pseudocystportal vein fistula manifests as residivating oligoarthritis, subcutaneous, bursal and osseal necrosis: a case report and review of literature / A. M. Hammar, J. Sand, J. Lumio [et al.] // Hepatogastroenterology. - 2002. Vol. 49. - P. 273-278.

34. Dawson B. C. Pancreatic pseudocyst rupture into the portal vein / B. C. Dawson, D. Kasa, M. A. Mazer // South Med. J. 2009. - Vol. 102. - P. 728-732.

35. Parikh S. Portal vein thrombosis / S. Parikh, R. Shah, P. Kapoor // Am. J. Med. - 2010. - Vol. 123. - P. 111-119.

36. Kim Y. I. Ischemic jejunal stenosis following acute pancreatitis with mesenteric panniculitis / Y. I. Kim, K. J. Choe, K. W. Choi // Korean J. Gastroenterol. - 1991. - Vol. 23. - P. 930-935.

37. Katz P. Colonic necrosis complicating postoperative pancreatitis / P. Katz, M. J. Dorman, A. H. Aufses Jr. // Ann. Surg. - 1974. - Vol. 179. - P. 403-405.

38. Stenosis of the colon due to chronic pancreatitis mimicking colon cancer / Y. D. Cho, S. J. Hong, J. H. Moon [et al.] // Korean J. Gastrointest. Endosc. - 1998. - Vol. 18. - P. 605-610.

39. Nottle P. Colonic infarction and pancreatitis: a case report / P. Nottle // Aust. N. Z. J. Surg. - 1980. - Vol. 50. - P. 184-185.

40. A case of jejunal infarction and perforation due to acute pancreatitis / J. Y. Chai, S. I. Yun, S. S. Bae [et al.] // Korean J. Gastroenterol. - 2004. - Vol. 43. - P. 120-124.

41. Griffiths R. W. Jejunal infarction as a complication of pancreatitis / R. W. Griffiths, P. W. Brown Jr. // Gastroenterology. - 1970. - Vol. 58. - P. 709-712.

42. Purushothaman K. Unusual presentation of spontaneous splenic haematoma due to severe pancreatitis: a cautionary tale / K. Purushothaman, D. W. Borowski // BMJ Case Rep. - 2012.

43. Spontaneous splenic rupture: a rare complication of acute pancreatitis in a patient with Crohn's disease / G. Mujtaba, J. Josmi, M. Arya, S. Anand // Case Rep. Gastroenterol. - 2011. Vol. 5. - P. 179-182.

44. Compared with parenteral nutrition, enteral feeding attenuates the acute phase response and improves disease severity in acute pancreatitis / A. C. Windsor, S. Kanwar, A. G. Li [et al.] // Gut. 1998. - Vol. 42. - P. 431-435.

45. Observations on the origin of ascites from experimental extra- hepatic portal congestion / C. L. Witte, Y. C. Chung, M. H. Witte [et al.] // Ann. Surg. - 1969. - Vol. 170. - P. 1002-1015.

46. Acute pancreatitis and upper gastrointestinal bleeding as presenting symptoms of a duodenal Brunner's gland hamartoma / E. Stermer, N. Elias, D. Keren [et al.] // Can. J. Gastroenterol. 2006. - Vol. 20. - P. 541-542.

47. Clinical and endoscopic features of gastric varices secondary to splenic vein occlusion / T. Sato, K. Yamazaki, J. Akaike [et al.] // Hepatol. Res. - 2008. - Vol. 38. - P. 1076-1082.

48. Li L. Treatment of rare gastric variceal bleeding in acute pancreatitis using embolization of the splenic artery combined with short gastric vein / L. Li, X. Zhao // Case Rep. Gastroenterol. - 2012. - Vol. 6. - P. 741-746.

49. Alpern M. D. Porta hepatis: duplex Doppler US with angiographic correlation / M. D. Alpern, J. M. Rubin, D. M. Williams // Radiology. - 1987. - Vol. 162. - P. 53-56.

50. Comparison of dynamic contrast-enhanced MRI and Doppler ultrasound in the preoperative assessment of the portal venous system / K. S. Naik, J. Ward, H. C. Irving [et al.] // Br. J. Radiol. - 1997. - Vol. 70. - P. 43-49.

51. Duplex Doppler endosonography in the diagnosis of splenic vein, portal vein, and portosystemic shunt thrombosis / M. J. Wiersema, A. Chak, K. K. Kopecky [et al.] // Gastrointest. Endosc. - 1995. - Vol. 42. - P. 19-26.

52. Improving image quality in portal venography with spectral CT imaging / L. Q. Zhao, W. He, J. Y [et al.] // Eur. J. Radiol. 2012. - Vol. 81. - P. 1677-1681.

53. Three-dimensional spiral CT angiography of the abdomen: initial clinical experience / G. D. Rubin, M. D. Dake, S. A. Napel [et al.] // Radiology. - 1993. - Vol. 186. - P. 147-152.

54. Brink J. A. Spiral CT angiography of the abdomen and pelvis: interventional applications / J. A. Brink // Abdom. Imaging. 1997. - Vol. 22. - P. 365-372.

55. Mesenteric venous thrombosis: diagnosis and noninvasive imaging // M. S. Bradbury, P. V. Kavanagh, R. E. Bechtold [et al.] // Radiographics. - 2002. - Vol. 22. - P. 527-541.

56. Role of contrast-enhanced 3D magnetic resonance portography in evaluating portal venous system compared with color Doppler ultrasonography / O. Cakmak, N. Elmas, S. Tamsel [et al.] // Abdom. Imaging. - 2008. - Vol. 33. - P. 65-71.

57. Retrospective study of 23 cases of hepatic infarction: CT findings and pathological correlations / S. Giovine, A. Pinto, S. Crispano [et al.] // Radiol. Med. - 2006. - Vol. 111. - P. 11-21. 58. Intra-abdominal hypertension and the abdominal compartment syndrome: updated consensus definitions and clinical practice guidelines from the World Society of the Abdominal Compartment Syndrome // A. W. Kirkpatrick, D. J. Roberts, J. De Waele [et al.] // Intensive Care Med. - 2013. - Vol. 39. - P. 1190-1206.

59. Splenic parenchymal complications of pancreatitis: CT findings and natural history / F. Rypens, J. Devière, M. Zalcman [et al.] // J. Comput. Assist. Tomogr. - 1997. - Vol. 21. - P. 89-93.

60. Management of acute non-cirrhotic and non-malignant portal vein thrombosis: a systematic review / T. C. Hall, G. Garcea, M. Metcalfe [et al.] // World J. Surg. - 2011. - Vol. 35. - P. 25102520.

61. Garcia-Pagán J. C. Extrahepatic portal vein thrombosis / J. C. Garcia-Pagán, M. Hernández-Guerra, J. Bosch // Semin. Liver Dis. - 2008. - Vol. 28. - P. 282-292.

62. de Franchis R. Revising consensus in portal hypertension: report of the Baveno $\mathrm{V}$ consensus workshop on methodology of diagnosis and therapy in portal hypertension / R. de Franchis, Baveno V Faculty // J. Hepatol. - 2010. - Vol. 53. - P. 762-768. 